\title{
REKOMENDASI MANAJEMEN LINGKUNGAN DI DAERAH ALIRAN SUNGAI DONDONG, KECAMATAN NGLIPAR, KABUPATEN GUNUNG KIDUL SEBAGAI MITIGASI BENCANA KEKERINGAN
}

\author{
Retno Wulandari*, Nurmaliyatul Khayah \\ Fakultas Geografi, Universitas Gadjah Mada D.I. Yogyakarta \\ *E-mail: retnowulandari.eno@gmail.com
}

\begin{abstract}
Abstrak
Daerah Aliran Sungai (DAS) Dondong terletak di Kecamatan Nglipar, Kabupaten Gunungkidul, D.I. Yogyakarta. DAS Dondong terdiri dari beberapa Bentuk lahan dengan variasi bentuk penggunaan lahan. DAS ini mengalami ketimpangan penggunaan lahan yaitu adanya ketidaksesuaian antara penggunaan lahan dengan kemampuan lahan yang ada. Hal ini diperparah oleh ketersediaan air meteorologis yang kurang, sehingga memicu terjadinya kekeringan. Kekeringan dapat mempengaruhi aktivitas penduduk setempat yang sebagian besar bekerja di sektor pertanian, sehingga diperlukan adanya manajemen terhadap penggunaan lahan DAS Dondong. Manajemen lingkungan DAS yang dilakukan didasarkan pada satuan Bentuk lahan yang ada di dalam DAS. Metode yang digunakan dalam penelitian ini adalah Neraca Air Throntwaite dan Subjective Matching Factors terhadap kemampuan dan kesesuaian lahan. Berdasarkan hasil Neraca Air dengan curah hujan probabilitas 60\%, DAS Dondong mengalami defisit air selama 11 bulan. Setelah dilakukan rekomendasi terhadap penggunaan lahan yang disesuaikan dengan kemampuan dan kesesuaian lahan, maka ketersediaan air meteorologis dihitung kembali menggunakan Neraca Air. Neraca Air hasil rekomendasi penggunaan lahan menunjukan bahwa kekeringan yang terjadi dapat dikurangi. Hal ini menggambarkan adanya hubungan antara Bentuk lahan, penggunaan lahan, dan kekeringan di DAS Dondong.
\end{abstract}

Kata kunci: kekeringan, kemampuan lahan, kesesuaian lahan, Neraca Air

\begin{abstract}
Dondong watershed is located in Nglipar Sub-district, Gunungkidul District, D.I. Yogyakarta. Dondong watershed consist of several landforms with its land use variation. Unsuitable land use between actual land use and land capability is the major issue in this Watershed. This problem become more complicated because of the meteorological water availability is less than its use. Drought may affect the activity of the local population, mostly working in the agricultural sector. Thus, it is necessarily to manage the land use in this watershed. Land use management in watershed is based on landform analysis. The methods used in this research are Thronthwaite Water Balance and Subjective Matching Factors to land capability and suitability. Based on the results of water balance analysis with precipitation probability of 60\%, Dondong watershed deficit for 11 months. This water balance is recalculated by the result of land use recommendation. The water deficit can be decreased through this land use recommendation. This research shows the relation between landform, land use, and drought in Dondong Watershed.
\end{abstract}

Keywords: drought, land capability, land suitability, Water Balance 


\section{PENDAHULUAN}

Daerah Aliran Sungai memiliki potensi sumberdaya yang besar di antaranya sumberdaya lahan dan air. Kemampuan lahan yang dimiliki oleh suatu wilayah dapat berbeda-beda. Hal ini mempengaruhi peruntukan penggunaan lahan. Penggunaan lahan tersebut idealnya disesuaikan dengan kemampuan lahan yang ada, sehingga terjadi kecocokan antara kebutuhan dan ketersediaan dalam manajemen lahan. Penyesuaian antara kemampuan lahan dan penggunaan lahan ini penting pula untuk mengurangi biaya manajemen lahan, sehingga dapat mengoptimalkan sumberdaya lahan dan air.

Hal tersebut dapat mengurangi dampak bencana kekeringan yang seringkali terjadi di Daerah Gunungkidul. Akan tetapi, penggunaan lahan kadang tidak sesuai dengan kemampuan lahan, sehingga dapat mempengaruhi biaya pengelolaan dan kelestarian dari lahan dan air tersebut. Menurut FAO dalam Arsyad (2000), lahan diartikan sebagai lingkungan fisik yang mencakup iklim, relief, tanah, air, vegetasi, dan benda di atasnya yang masih berpengaruh terhadap penggunaan lahan.

Pengertian lahan ini juga mencakup hasil kegiatan manusia pada saat ini dan masa lampau. Sifat lahan menunjukkan kemungkinan penampilan lahan untuk penggunaan lahan tertentu. Sifat lahan ini dapat mempengaruhi ketersediaan air, peredaran udara, perkembangan kepekaan erosi, dan ketersediaan unsur hara (Sartohadi dkk., 2013). Oleh karena itu, penting dilakukan evaluasi lahan untuk menilai kemampuan dan kesesuaian lahan.

Evaluasi lahan merupakan suatu proses penilaian sumberdaya lahan untuk tujuan tertentu dengan menggunakan suatu pendekatan atau cara yang sudah teruji. Inti evaluasi lahan tersebut adalah membandingkan persyaratan yang diminta oleh tipe penggunaan lahan yang akan diterapkan dengan sifat atau kualitas lahan yang dimiliki oleh lahan yang akan digunakan (Hardjowigeno dan Widiatmaka, 2007). Evaluasi lahan ini menghasilkan informasi yang kemudian digunakan sebagai arahan penggunaan lahan sesuai dengan keperluannya (Ritung dkk., 2007). Evaluasi lahan ini di dalamnya juga mencakup evaluasi terhadap sumber daya air. Konsep sumberdaya air bersifat multidimensi yang tidak hanya terbatas pada karakteristik fisik (hidrologi dan hidrogeologi) dan persediaan, namun juga mencakup hal lainnya seperti dimensi lingkungan, sosial, dan ekonomi.

Ketersediaan air menurut Direktorat Irigasi (1980) dalam Triatmojo (2008) adalah jumlah air atau debit yang ada di suatu lokasi dengan jumlah tertentu dan pada waktu tertentu. Pemanfaatan air erat kaitannya dengan kebutuhan air yang merupakan jumlah air yang dipergunakan oleh manusia untuk keperluan rumah tangga, pertanian, industri, perikanan, pembentukan tenaga hidrologi, dan navigasi serta rekreasi (Notodiharjo, 1982 dalam Kartiwa, 2010).

Penelitian ini bertujuan untuk memberikan rekomendasi manajemen penggunaan lahan di DAS Dondong. Manajemen penggunaan lahan yang dilakukan mendasarkan pada satuan Bentuk lahan, kemampuan lahan, dan kesesuaian lahan. Rekomendasi menajemen penggunaan lahan juga mempertimbangkan neraca air meteorologis DAS yang dimaksudkan sebagai salah satu upaya mitigasi dalam mengantisipasi bencana kekeringan.

\section{METODA}

\section{Kemampuan Lahan}

Klasifikasi kemampuan lahan adalah penilaian lahan secara parametrik dan sistematik berdasarkan pada sifat yang merupakan potensi dan penghambat dari kondisi fisik lahan. Sistem klasifikasi kemampuan lahan yang digunakan mengacu pada Arsyad (2000) yang telah dimodifikasi dengan pertimbangan ketersediaan data, sehingga digunakan 5 parameter kemampuan lahan yang meliputi kemiringan lereng, tekstur, kedalaman, batuan permukaan, dan permeabilitas tanah. Hubungan antara kelas kemampuan dengan intensitas dan macam penggunaan lahan dapat dilihat dalam Tabel 1 . 
Tabel 1 Skema Hubungan antara Kelas Kemampuan Lahan dengan Intensitas dan Macam Penggunaan Lahan (Hardjowigeno dan Widiatmaka, 2007)

\begin{tabular}{|c|c|c|c|c|c|c|c|c|}
\hline \multirow[b]{2}{*}{ 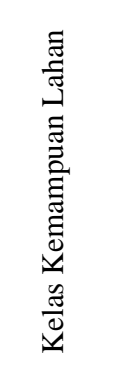 } & \multicolumn{8}{|c|}{ Intensitas Dan Pilihan Penggunaan Meningkat } \\
\hline & 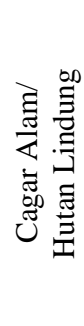 & 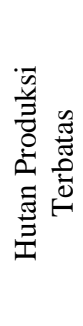 & 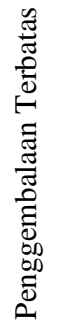 & 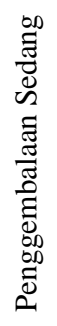 & 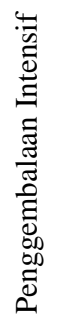 & 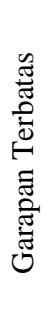 & 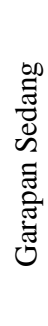 & 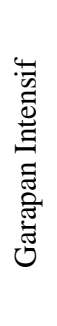 \\
\hline \multirow{8}{*}{ 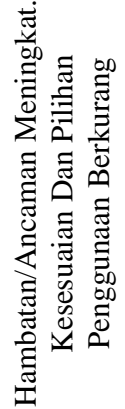 } & I & & & & & & & \\
\hline & II & & & & & & & \\
\hline & III & & & & & & & \\
\hline & IV & & & & & & & \\
\hline & $\mathrm{V}$ & & & & & & & \\
\hline & VI & & & & & & & \\
\hline & VII & & & & & & & \\
\hline & VIII & & & & & & & \\
\hline
\end{tabular}

\section{Kesesuaian Lahan}

Sistem evaluasi kesesuaian lahan yang digunakan adalah Sistem Parametrik Metode Matching. Metode ini didasarkan pada pencocokan antara kriteria kesesuaian lahan dengan data kualitas lahan. Metode Matching memiliki beberapa macam jenis metode salah satunya Subjective Matching. Evaluasi penggunaan lahan yang dilakukan mengambil 2 komoditas pertanian dan 2 penggunaan lahan non-pertanian. Komoditas pertanian berupa padi dan akasia. Penggunaan lahan non pertanian sebagai pemukiman dan tempat rekreasi (Hardjowigeno dan Widiatmaka, 2007).

\section{Rekomendasi Penggunaan Lahan}

Rekomendasi penggunaan lahan didasarkan pada karakteristik Bentuk lahan, kemampuan lahan, dan kesesuaian lahan di DAS Dondong. Penggunaan lahan yang digunakan adalah permukiman, pertanian padi, perkebunan akasia, dan tempat rekreasi. Rekomendasi manajemen penggunaan lahan ini juga mempertimbangkan neraca air meteorologis DAS yang dihitung dengan persamaan Thronthwaite (Soewarno, 2000).

\section{HASIL DAN PEMBAHASAN}

\section{Kemampuan Lahan}

DAS Dondong memiliki enam satuan Bentuk lahan seperti yang terlihat pada Gambar 1 . Satuan bentuk lahan tersebut adalah puncak pegunungan struktural berbatuan breksi-batu apung, lereng atas pegunungan struktural berbatuan breksi-batu apung, lereng tengah pegunungan struktural berbatuan breksi-andesit, lereng bawah pegunungan struktural berbatuan breksi-andesit, lereng kaki pegunungan struktural, dan perbukitan struktural berbatuan pasir-gampingan. Satuan lahan tersebut dibedakan atas kenampakan yang terlihat dalam citra, peta kontur, dan kenampakan tiga dimensi berupa tin. Penentuan satuan lahan juga divalidasi dengan melakukan survei lapangan.

Gambar 2 menunjukkan kemampuan lahan dengan menggunakan Metode Subjective Matching menghasilkan 3 kelas kemampuan lahan untuk wilayah DAS Dondong, yaitu kelas IIl, IIIl, dan IVl (Tabel 1). Metode ini menggunakan lereng $(l)$ sebagai penghambat terberat dalam kemampuan lahan.

Kemampuan lahan kelas IIl dimiliki oleh bentuk lahan lereng kaki perbukitan struktural. Kelas II cocok untuk digunakan sebagai pertanian intensif karena memiliki faktor yang mendukung. Faktor tersebut antara lain lereng yang landai atau berombak, tanah bertekstur lempung, jumlah kerikil/batu yang sedikit, kedalaman tanah efektif dangkal, dan permeabilitas yang sedikit. Lereng yang landai dan berombak cocok untuk lahan pertanian karena memudahkan petani dalam mengolah lahan. Hal ini juga dapat mengurangi biaya pengelolaan lahan. Modifikasi lahan masih dapat dilakukan pada Bentuk lahan Lereng Kaki karena terdapat topografi yang berombak.

Bentuk lahan lereng tengah pegunungan struktural berbatuan breksi-andesit, lereng atas pegunungan struktural berbatuan breksibatuapung, dan puncak pegunungan struktural berbatuan breksi-batuapung memiliki kelas kemampuan lahan ivl. Kelas IV mempunyai kemampuan lahan untuk dijadikan lahan 
pertanian dengan intensitas yang terbatas. Hal tersebut disebabkan oleh kendala topografi yang miring atau berbukit. Pengolahan membutuhkan biaya dan usaha yang lebih daripada mengolah lahan dengan kelas kemampuan II1. Pembuatan terasering juga harus diperhatikan dengan baik agar tidak memunculkan bahaya lain seperti erosi dan tanah longsor. Terasering dapat digunakan untuk mengolah tanaman semusim atau pergiliran dengan tanaman penutup tanah/makanan ternak/pupuk hijau selama 3-5 tahun.

\section{Kesesuaian Lahan}

Menurut Tabel 2 lereng kaki perbukitan struktural adalah satu-satunya bentuk lahan yang sesuai untuk ditanami komoditas padi. Nilai kesesuaian ini dianggap ideal karena nilai produktivitas padi pada bentuk lahan ini paling tinggi. Penghambat utama bentuk lahan ini adalah kedalaman tanah. Nilai ini tidak terlalu signifikan terhadap pertumbuhan padi karena kebutuhan untuk perakaran hanya membutuhkan tanah berkedalaman sedang.

Faktor pembatas kesesuaian lahan untuk akasia di DAS Dondong menggunakan kedalaman tanah dengan asumsi tanaman akasia merupakan tanaman berkayu yang berakar tunggang sehingga membutuhkan tanah cukup tebal untuk dapat hidup. Berdasarkan metode tersebut, bentuk lahan di DAS Dondong dinilai kesesuaian lahannya, bentuk lahan lereng kaki perbukitan struktural memiliki nilai $\mathrm{N} 2 \mathrm{~d}$ yang artinya tanaman akasia sangat tidak sesuai hidup di wilayah ini.

Kedalaman tanah di lereng kaki perbukitan struktural tergolong dangkal karena tidak terjadi proses sedimentasi dari lereng perbukitan di atasnya. Tanah di lereng kaki perbukitan struktural berasal dari proses sungai di sekitarnya.Puncak pegunungan struktural berbatuan breksi-batu apung, lereng tengah pegunungan struktural berbatuan breksi-andesit, dan lereng atas pegunungan struktural berbatuan breksi-batu apung memiliki nilai S1t yang artinya sangat sesuai untuk ditanami akasia karena merupakan daerah tinggi dengan lereng curam, namum memiliki faktor pembatas berupa tekstur tanah. Bentuk lahan lereng bawah pegunungan struktural berbatuan breksi-andesit dan perbukitan struktural berbatuan pasirgampingan memiliki nilai S2 yang artinya sesuai untuk ditanami akasia. Lereng dibentuk lahan ini tergolong bergelombang dan agak miring, namun tidak menjadi faktor yang terlalu berpengaruh terhadap pertumbuhan tanaman akasia.

Tabel 3 menunjukkan klasifikasi kesesuaian lahan non-pertanian berupa permukiman dan tempat rekreasi. Kesesuaian lahan permukiman dengan metode subjective matching terbagi dalam 3 kelas yaitu kelas baik, kelas sedang, dan kelas jelek. Masing-masing kelas menggambarkan tingkat kesesuaian lahan berdasarkan kemampuan lahan jika diperuntukan untuk permukiman. Kelas baik menggambarkan lahan tersebut dapat dimanfaatkan sebagai permukiman. Kelas sedang menunjukkan bahawa lahan tersebut dapat dimanfaatkan untuk permukiman dengan melakukan pengelolaan terlebih dahulu. Kelas jelek menandakan bahwa lahan tidak dapat dimanfaatkan untuk permukiman.

Metode subjective matching menghasilkan kelas kesesuaian lahan untuk lokasi piknik berupa kelas sedang dan kelas baik. Penentuan satuan bentuk lahan puncak pegunungan struktural berbatuan breksi-batu apung, lereng atas pegunungan struktural berbatuan breksi-batu apung, dan lereng tengah pegunungan struktural berbatuan breksi-andesit sebagai lokasi yang paling sesuai untuk lokasi piknik dengan metode ini didasarkan pada beberapa asumsi.

Parameter kemiringan lereng yang semakin tinggi diasumsikan akan menjadi daya tarik wilayah tersebut sebagai tempat piknik. Wilayah dengan kemiringan lereng yang besar atau lebih tinggi memiliki kelebihan karena dapat melihat pemandangan bagian DAS di bawahnya. Lereng bagian atas juga umumnya lebih banyak memiliki tutupan vegetasi, sehingga lebih cocok untuk tempat berpiknik. 
Tabel 2 Klasifikasi DAS Dondong untuk Pertanian Padi dan Perkebunan Akasia

\begin{tabular}{ccccccc}
\hline \multirow{2}{*}{$\begin{array}{c}\text { Penggunaan } \\
\text { Lahan }\end{array}$} & $\begin{array}{c}\text { Lereng Kaki } \\
\text { Pegunungan }\end{array}$ & $\begin{array}{c}\text { Puncak } \\
\text { Pegunungan }\end{array}$ & $\begin{array}{c}\text { Lereng Tengah } \\
\text { Pegunungan }\end{array}$ & $\begin{array}{c}\text { Lereng } \\
\text { Bawah } \\
\text { Pegunungan }\end{array}$ & $\begin{array}{c}\text { Perbukitan } \\
\text { Struktural }\end{array}$ & $\begin{array}{c}\text { Lereng Atas } \\
\text { Pegunungan }\end{array}$ \\
\hline Akasia & N2d & S1t & S1t & S2 & S2 & S1t \\
Padi & S1d & Ntl & Ntl & Nl & Nl & Ntl \\
\hline
\end{tabular}

Tabel 3 Klasifikasi Kesesuaian Lahan di DAS Dondong

\begin{tabular}{|c|c|c|c|c|c|c|}
\hline \multirow[b]{2}{*}{$\begin{array}{l}\text { Penggunaan } \\
\text { Lahan }\end{array}$} & \multicolumn{6}{|c|}{ Bentuk Lahan } \\
\hline & $\begin{array}{c}\text { Lereng Kaki } \\
\text { Pegunungan } \\
\text { Struktural } \\
\text { Berbatuan } \\
\text { Batupasir }\end{array}$ & $\begin{array}{c}\text { Puncak } \\
\text { Pegunungan } \\
\text { Struktural } \\
\text { Berbatuan } \\
\text { Breksi-Batu } \\
\text { apung } \\
\end{array}$ & $\begin{array}{l}\text { Lereng Tengah } \\
\text { Pegunungan } \\
\text { Struktural } \\
\text { Berbatuan } \\
\text { Breksi-Andesit }\end{array}$ & $\begin{array}{l}\text { Lereng Bawah } \\
\text { Pegunungan } \\
\text { Struktural } \\
\text { Berbatuan } \\
\text { Breksi-Andesit }\end{array}$ & $\begin{array}{c}\text { Perbukitan } \\
\text { Struktural } \\
\text { Berbatuan } \\
\text { Pasir- } \\
\text { Gampingan }\end{array}$ & $\begin{array}{c}\text { Lereng Atas } \\
\text { Pegunungan } \\
\text { Struktural } \\
\text { Berbatuan } \\
\text { Breksi-Batu } \\
\text { apung }\end{array}$ \\
\hline Permukiman & Baik & Jelek & Jelek & Sedang & Sedang & Jelek \\
\hline Rekreasi & Sedang & Baik & Baik & Sedang & Sedang & Baik \\
\hline
\end{tabular}

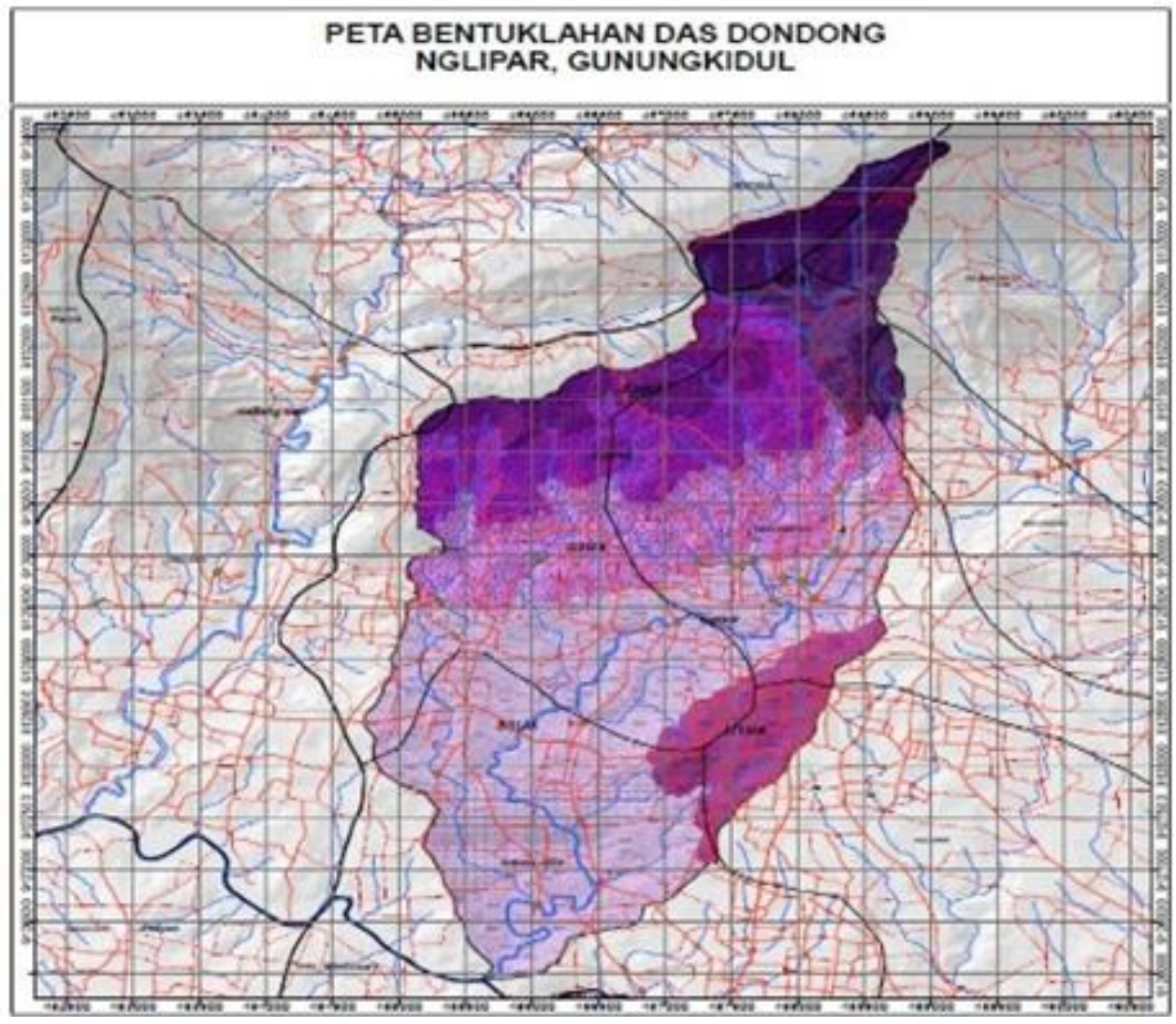

Sumber: Jurusan Geografi Lingkungan, UGM. (2014).
Keterangan:

Puncak pegunungan structural berbatuan breksi batu apung

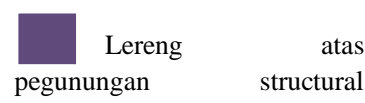
berbatuan breksi batu apung

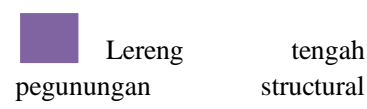

berbatuan breksi andesit

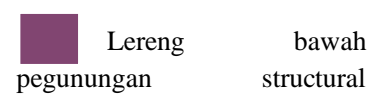

berbatuan breksi andesit

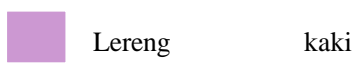

pegunungan structural

Perbukitan structural

berbatuan pasir gampingan

Gambar 1. Peta lahan DAS Dondong 


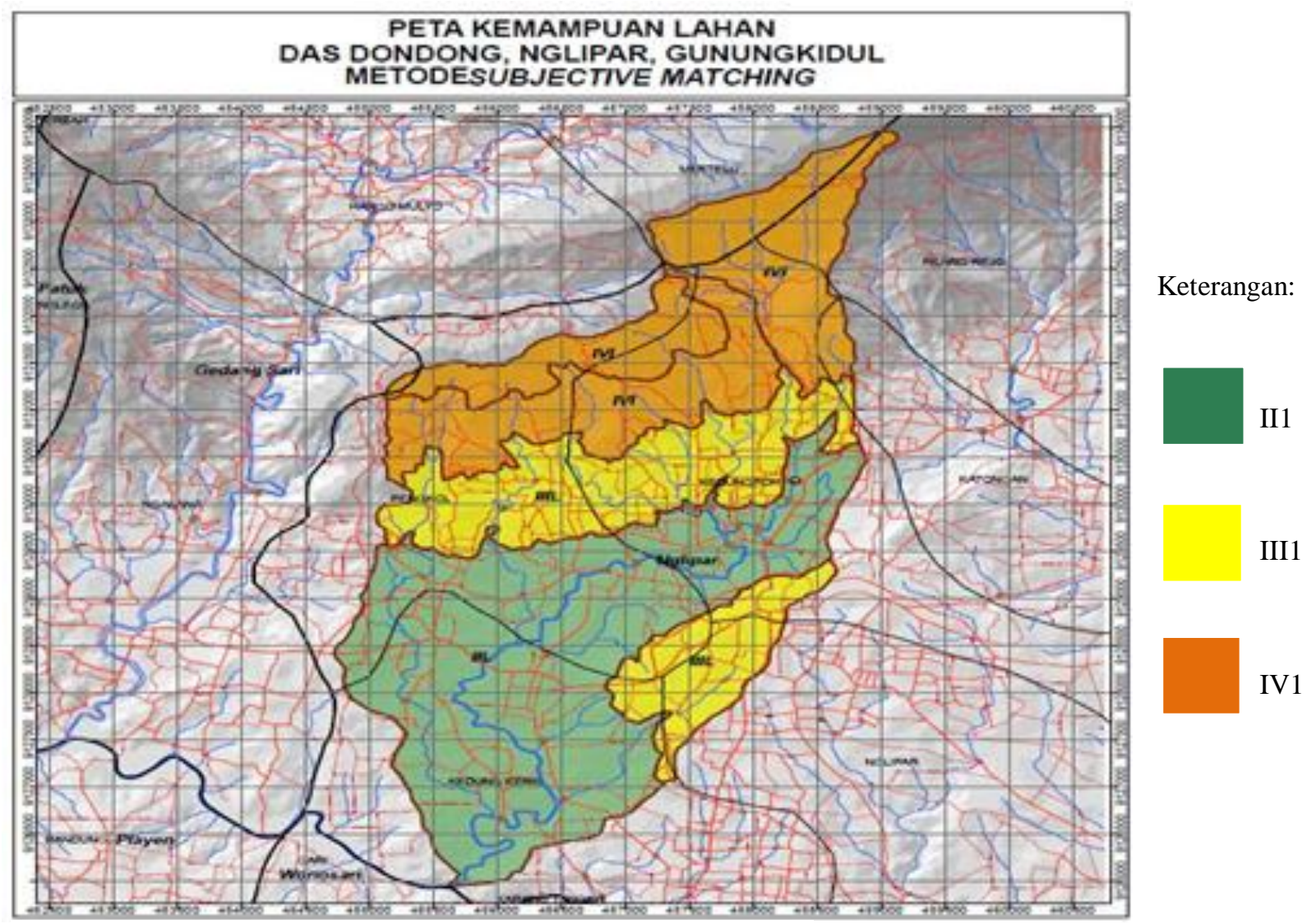

Sumber: Jurusan Geografi Lingkungan, UGM. (2014).

Gambar 2. DAS Metode Subjective Matching

\section{Ketimpangan Penggunaan Lahan}

Ketimpangan lahan di DAS Dondong ditunjukkan pada Gambar 3. Ketimpangan lahan memiliki dua klasifikasi yaitu sesuai dan tidak sesuai yang dilihat dari kemampuan lahan metode subjective matching dan penggunaan lahan di setiap bentuk lahan. Penggunaan lahan di DAS Dondong ini ditunjukkan pada Gambar 4.

Peta ketimpangan penggunaan lahan DAS Dondong memperlihatkan bahwa terdapat penggunaan lahan yang tidak sesuai di masingmasing bentuk lahan. Kelas tidak sesuai ini lebih banyak ditemukan pada bentuk lahan di sekitar lereng tengah pegunungan struktural berbatuan breksi andesit dan puncak pegunungan struktural berbatuan breksi-batu apung.

\section{Rekomendasi Manajemen Penggunaan Lahan}

Rekomendasi manajemen penggunaan lahan di DAS Dondong ditunjukkan pada Gambar 5. Lereng Kaki Pegunungan Struktural Berbatuan Batu pasir direkomendasikan sebagai lahan pertanian padi. Hal ini salah satunya didasarkan pada pertimbangan ketersediaan lahan dibentuk lahan tersebut merupakan yang paling luas dibandingkan satuan bentuk lahan lainnya. Luasan wilayah bentuk lahan ini mencapai 800 ha. Komoditas pertanian padi menggunakan areal terluas karena kemampuan pada bentuk lahan lereng kaki pegunungan ini masuk ke dalam kelas kemampuan 1 yang dianggap paling produktif, sehingga dapat dioptimalkan untuk produksi padi secara intensif. 
Tingkat produktivitas padi dipengaruhi oleh kemiringan lereng yang landai karena laju erosi kecil, batuan penutup permukaan yang sedikit, dan lokasi yang dekat dengan aliran sungai utama DAS Dondong menjamin ketersediaan air untuk pengolahan lahan intensif. Dengan bertambahnya tingkat produktifitas padi diharapkan dapat meningkatkan tingkat perekonomian warga sekaligus menjamin ketahanan pangan dalam DAS. Bentuk lahan lereng bawah pegunungan struktural dan perbukitan struktural berbatuan pasir-gampingan direkomendasikan sebagai lahan pemukiman. Kesesuaian lahan untuk pemukiman ini mempertimbangkan kemiringan lereng dan persentase batuan permukaan. bentuk lahan lereng bawah pegunungan struktural memiliki kemiringan lereng dan batuan yang memenuhi kriteria yang sesuai untuk lahan pemukiman. Kelas kemampuan lahan pada perbukitan struktural berbatuan pasir-gampingan dapat ditingkatkan dengan upaya modifikasi. Upaya modifikasi dilakukan dengan menurunkan persentase batuan permukaan yang ada. Rekomendasi keberadaaan pemukiman di bentuk lahan lereng bawah dan perbukitan struktural berbatuan pasir-gampingan juga mempertimbangkan penggunaan lahan sawah di lereng kaki yang bersebelahan secara langsung, sehingga akses petani terhadap lahan pun terhubung secara baik. Letak pemukiman yang tidak berada di relief paling bawah juga mampu menghindarkan pemukiman dari bahaya banjir dari luapan sungai karena aliran permukaan akan lebih dahulu menggenangi lereng kaki pegunungan struktural.

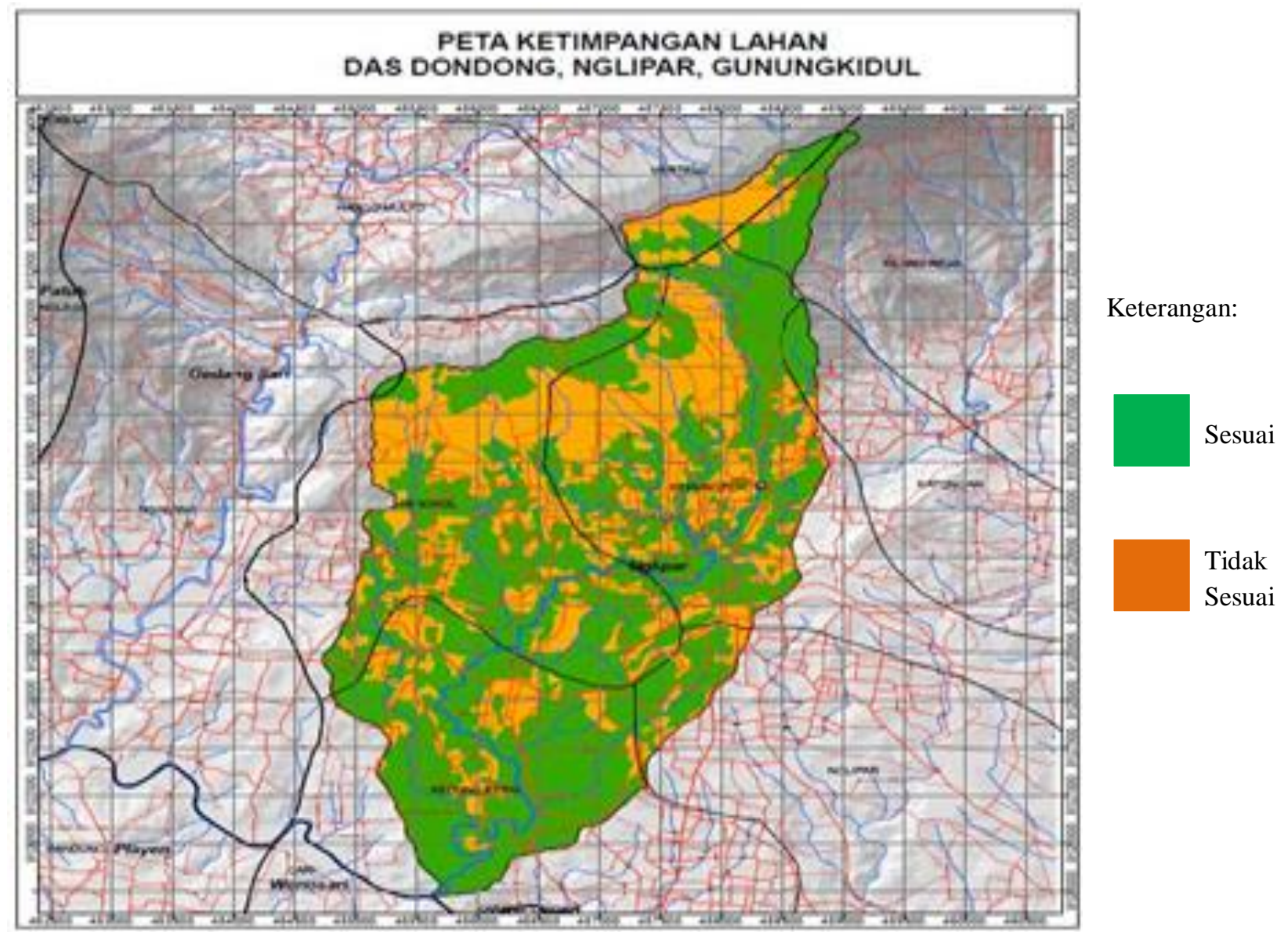

Sumber: Jurusan Geografi Lingkungan, UGM. (2014).

Gambar 3. Ketimpangan Lahan DAS Dondong 


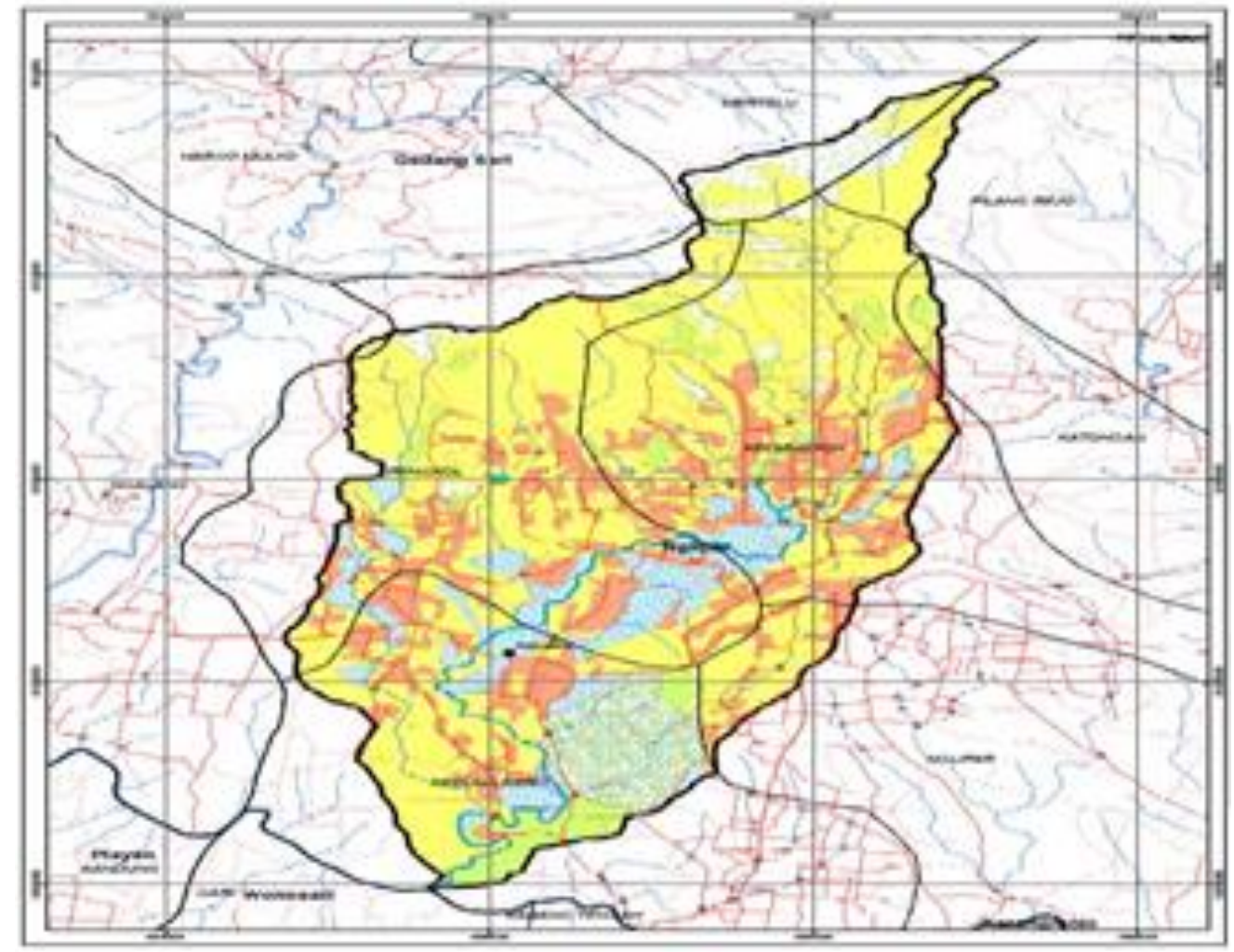

Sumber: Jurusan Geografi Lingkungan, UGM. (2014).

Gambar 4. Penggunaan Lahan DAS Dondong

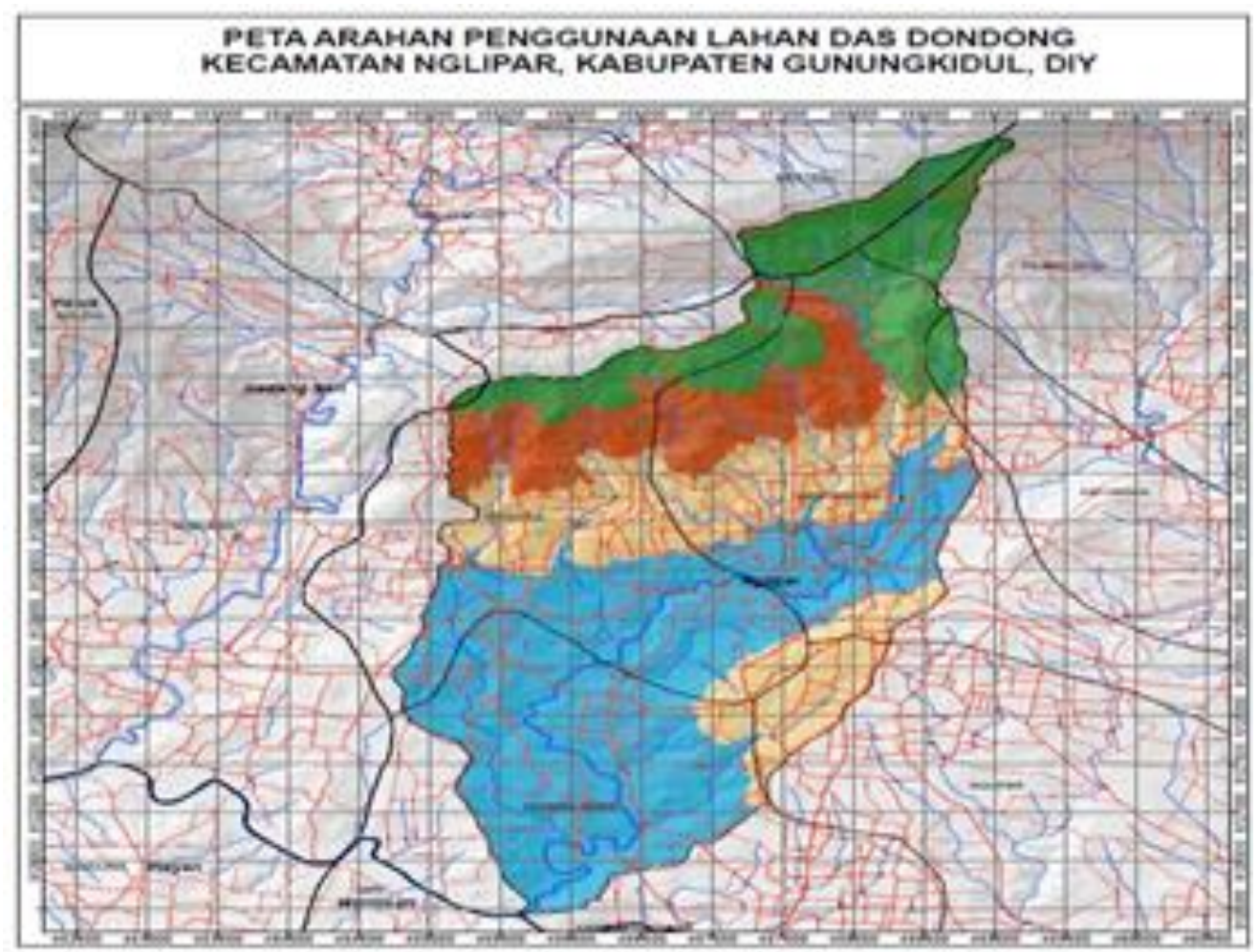

Keterangan:

Sumber: Jurusan Geografi Lingkungan, UGM. (2014).

Gambar 5. Arahan Penggunaan Lahan DAS 
Bentuk lahan lereng tengah direkomendasikan sebagai tempat rekreasi. Tempat rekreasi yang dimaksud adalah berupa ruang terbuka hijau yang digunakan untuk bersantai bersama keluarga. Hal ini disebabkan lereng tengah pegunungan struktural berbatuan breksi-andesit menyediakan ruang dan pemandangan yang memadai untuk menarik minat wisatawan. Tempat rekreasi menambah pendapatan warga setempat karena menciptakan ruang perekonomian baru melalui usaha-usaha mikro hingga kecil di sekitar tempat rekreasi tersebut. Pemilihan lokasi tersebut mempertimbangkan aspek konservasi lahan. Lahan terbuka hijau diharapkan mampu mengurangi laju erosi dengan adanya rerumputan dan pepohonan. Pemilihan penggunaan lahan juga mempertimbangkan tidak adanya ancaman bahaya seperti longsor dan banjir pada Bentuk lahan ini. Komoditas lain yang disarankan adalah perkebunan akasia. Akasia dipilih karena memiliki nilai jual tinggi dengan masa tanam yang relatif singkat. Bentuk lahan puncak pegunungan struktural berbatuan breksi-batu apung dan lereng atas pegunungan struktural berbatuan breksi-batu apung sudah mulai ditanami akasia dengan masa tanam 3-5 tahun. pemilihan bentuk lahan lereng atas dan puncak pegunungan struktural berbatuan breksi-batu apung sebagai perkebunan akasia disebabkan oleh tingkat kesesuaian bentuk lahan tersebut memadai untuk pertumbuhan akasia. Tanaman akasia memiliki perakaran dalam, sehingga dapat menahan laju erosi yang terjadi di wilayah dengan kemiringan lereng curam tanpa kebutuhan air yang besar. Perhitungan neraca air di antaranya bertujuan untuk mengetahui ketersediaan air permukaan dan sub-permukaan tanah, menaksir pola penggunaan air yang tersedia, dan membantu menyeimbangkan jumlah air yang lebih dan kekurangan (Hadisusanto, 2010). Tabel 4 menunjukkan perhitungan neraca air meteorologis di DAS Dondong. Ketersediaan air permukaan di DAS Dondong menurut neraca air meteorologis lebih banyak terdapat pada Bulan Desember Februari, sedangkan pada bulan-bulan lainnya mengalami kekurangan air. Curah hujan menghasilkan surplus pada Bulan Januari dan Februari. Dengan demikian, bulan-bulan berikutnya mengalami defisit air. Defisit air total dalam setahun di DAS Dondong berdasarkan hasil perhitungan neraca air mencapai 769,68 $\mathrm{mm}$ dan surplus air sebesar $182,16 \mathrm{~mm}$ padahal jumlah surplus yang terjadi tersebut merupakan sumberdaya air yang dapat dimanfaatkan.

Tabel 4 Neraca Air DAS Dondong

\begin{tabular}{crrrrrrrrrrrr}
\hline & Jan & Feb & \multicolumn{1}{c}{ Mar } & \multicolumn{1}{c}{ Apr } & May & Jun & Jul & Aug & Sep & Oct & Nov & Dec \\
\hline P & 246.66 & 219.27 & 132.77 & 81.73 & 10.17 & 4.06 & 1.23 & 0.97 & 1.10 & 9.43 & 93.36 & 191.34 \\
EP & 149.36 & 134.41 & 140.12 & 138.70 & 130.37 & 109.31 & 118.05 & 106.53 & 118.65 & 142.52 & 148.87 & 142.72 \\
P-EP & 97.31 & 84.86 & -7.35 & -56.97 & -120.20 & -105.25 & -116.83 & -105.56 & -117.55 & -133.09 & -55.52 & 48.62 \\
APWL & 0.00 & 0.00 & 7.35 & 64.31 & 184.51 & 289.76 & 406.59 & 512.15 & 629.69 & 762.78 & 818.30 & 0.00 \\
St0 & 184.37 & 184.37 & 184.37 & 184.37 & 184.37 & 184.37 & 184.37 & 184.37 & 184.37 & 184.37 & 184.37 & 184.37 \\
St & 184.37 & 184.37 & 177.17 & 130.08 & 67.78 & 38.30 & 20.33 & 11.47 & 6.06 & 2.95 & 2.18 & 184.37 \\
$\Delta$ St & 0.00 & 0.00 & -7.20 & -47.09 & -62.30 & -29.48 & -17.98 & -8.86 & -5.41 & -3.12 & -0.77 & 182.19 \\
Ea & 149.36 & 134.41 & 139.97 & 128.82 & 72.47 & 33.54 & 19.20 & 9.83 & 6.51 & 12.55 & 94.12 & 9.15 \\
S & 97.31 & 84.86 & 0.00 & 0.00 & 0.00 & 0.00 & 0.00 & 0.00 & 0.00 & 0.00 & 0.00 & 0.00 \\
D & 0.00 & 0.00 & 0.15 & 9.88 & 57.90 & 75.77 & 98.85 & 96.70 & 112.14 & 129.97 & 54.75 & 133.57 \\
DRO & 48.65 & 91.08 & 42.43 & 0.00 & 0.00 & 0.00 & 0.00 & 0.00 & 0.00 & 0.00 & 0.00 & 0.00 \\
& & & & & & & & & & & & \\
\hline
\end{tabular}


Tabel 5 Neraca Air Arahan DAS Dondong

\begin{tabular}{crrrrrrrrrrrr}
\hline & \multicolumn{1}{c}{ Jan } & \multicolumn{1}{c}{ Feb } & \multicolumn{1}{c}{ Mar } & \multicolumn{1}{c}{ Apr } & \multicolumn{1}{c}{ May } & \multicolumn{1}{c}{ Jun } & \multicolumn{1}{c}{ Jul } & Aug & Sep & Oct & Nov & Dec \\
\hline P & 246.6 & 219.2 & 132.7 & 81.7 & 10.1 & 4 & 1.2 & 0.9 & 1.1 & 9.4 & 93.3 & 191.3 \\
EP & 149.3 & 134.4 & 140.1 & 138.7 & 130.3 & 109.3 & 118.0 & 106.5 & 118.6 & 142.5 & 148.8 & 142.7 \\
P-EP & 97.3 & 84.8 & -7.3 & -56.9 & -120.2 & -105.2 & -116.8 & -105.5 & -117.5 & -133 & -55.5 & 48.6 \\
APWL & 0.00 & 0.00 & 7.3 & 64.3 & 184.5 & 289.7 & 406.5 & 512.1 & 629.6 & 762.7 & 818.3 & 0.00 \\
St0 & 200.5 & 200.5 & 200.5 & 200.5 & 200.5 & 200.5 & 200.5 & 200.5 & 200.5 & 200.5 & 200.5 & 200.5 \\
St & 200.5 & 200.5 & 193.3 & 145.5 & 79.9 & 47.3 & 26.4 & 15.6 & 8.6 & 4.4 & 3.3 & 200.5 \\
$\Delta$ St & 0.00 & 0.00 & -7.2 & -47.8 & -65.6 & -32.6 & -20.8 & -10.8 & -6.9 & -4.2 & -1 & 197.1 \\
Ea & 149.3 & 134.4 & 139.9 & 129.5 & 75.7 & 36.7 & 22.1 & 11.7 & 8 & 13.6 & 94.4 & 142.7 \\
S & 97.3 & 84.8 & 0.00 & 0.00 & 0.00 & 0.00 & 0.00 & 0.00 & 0.00 & 0.00 & 0.00 & 0.00 \\
D & 0.00 & 0.00 & 0.1 & 9.1 & 54.5 & 72.6 & 95.9 & 94.7 & 110.6 & 128.8 & 54.4 & 0.00 \\
DRO & 48.6 & 91 & 42.4 & 0.00 & 0.00 & 0.00 & 0.00 & 0.00 & 0.00 & 0.00 & 0.00 & 0.00 \\
& & & & & & & & & & &
\end{tabular}

Tabel 5 menunjukkan perhitungan neraca air arahan di DAS Dondong. Hasil perhitungan neraca air dari arahan penggunaan lahan menunjukkan nilai defisit yang berbeda dengan neraca air aktual di DAS Dondong. Defisit air aktual di DAS tersebut sebesar 769,67 mm/tahun untuk curah hujan dengan probabilitas $60 \%$ berkurang menjadi sebesar $621,11 \mathrm{~mm} /$ tahun. Berdasarkan perhitungan tersebut, jumlah defisit air yang terjadi pada neraca air aktual di DAS ini lebih besar dari pada jumlah defisit pada neraca air arahan. Neraca air arahan diperoleh dari perubahan pada nilai kelembaban cadangan lengas tanah (Sto). Perubahan Sto dihitung dari kemampuan tanah menahan air atau Water Holding Capacity (WHC). Kemampuan tanah menahan air diperoleh berdasarkan hasil perkalian antara persentase luas penggunaan lahan, air tersedia, dan kedalaman zona perakaran. Kelebihan air hujan atas evapotranspirasi akan diserap tanah dalam bentuk simpanan lengas tanah. Apabila simapanan lengas tanah tersebut mencapai WHC maka semua kelebihan air hujan akan menjadi runoff (Djuwansah dan Narulita, 2006).

\section{KESIMPULAN DAN SARAN}

Berdasarkan peta arahan penggunaan lahan di DAS Dondong, dapat dirumuskan rekomendasi manjemen lingkungan sebagai berikut: Lokasi permukiman direkomendasikan pada bentuk lahan lereng bawah pegunungan struktural dan perbukitan struktural. Lahan pertanian padi direkomendasikan pada lereng kaki pegunungan struktural. Lahan perkebunan akasia direkomendasikan pada puncak dan lereng atas pegunungan struktural. Tempat rekreasi direkomendasikan pada lereng tengah pegunungan struktural.

\section{Ucapan Terima Kasih}

Ucapan terima kasih kepada Prof. Dr. rer.nat. Junun Sartohadi, M.Sc., Dr. Danang Srihatmoko, Dr. M. Widyastuti, M.T., Dr. M. Pramono Hadi, M.Sc., Dr. Slamet Suprayogi, M.S., dan Ahmad Cahyadi, M.Sc. selaku dosen pembimbing, Tim 10 Penelitian Analisis Sumberdaya Lahan dan Air (Annisa Mutia I., Puguh Dharmawan, Widha Ayu N.P.H, dan Ratna Prabaningrum) yang sangat berkontribusi dalam penelitian ini, serta masyarakat Kecamatan Nglipar, Kabupaten Gunungkidul, D.I.Yogyakarta.

\section{DAFTAR PUSTAKA}

Arsyad, S. 2000. Konservasi Tanah dan Air. IPB Press.

Djuwansah, M.R. dan Narulita, I. 2006. Neraca Air Spasial di Bagian Hulu DAS Citarum sebagai Basis Data Anggaran Air. Teknologi Indonesia, 29(1).

Hadisusanto, N. 2010. Aplikasi Hidrologi. Jogja Mediautama. 
Hardjowigeno, S. dan Widiatmaka. 2007. Ritung, S., Wahyunto, Agus, F., dan Hidayat, H. Evaluasi Kesesuaian Lahan dan 2007. Panduan Evaluasi Kesesuaian Perencanaan Tataguna Lahan. UGM Lahan dengan Contoh Peta Arahan Press.

Kartiwa, B. 2010. Identifikasi dan Analisis Neraca Ketersediaan-Kebutuhan Air Pertanian Mendukung Peningkatan IP dan Pengembangan Padi IP 400 di

Sumatera Barat, Lampung, Sulawesi Selatan, dan Sulawesi Barat. Balai Penggunaan Lahan Kabupaten Aceh Barat. Balai Penelitian Tanah dan World Argoforestry Centre (ICRAF).

Sartohadi, J., Suratman, Jamulya, dan Dewi N.I.S. 2013. Pengantar Geografi Tanah. Pustaka Pelajar.

Soewarno. 2000. Hidrologi Operasional Jilid Kesatu. Citra Aditya Bakti.

Penelitian Agroklimat dan Hidrologi.

Triatmodjo, B. 2013. Hidrologi Terapan. Beta Offset. 